\title{
Electrochemical characterization of Prussian blue type nickel hexacyanoferrate redox mediator for potential application as charge relay in dye-sensitized solar cells
}

\author{
Iwona A. Rutkowska • Adam Andrearczyk • \\ Sylwia Zoladek • Monika Goral • \\ Kazimierz Darowicki • Pawel J. Kulesza
}

Received: 4 May 2011 /Revised: 13 July 2011 / Accepted: 14 July 2011 / Published online: 9 August 2011

(C) The Author(s) 2011. This article is published with open access at Springerlink.com

\begin{abstract}
A polynuclear electronically/ionically (redox) conducting mixed-valent inorganic material such as nickel (II) hexacyanoferrate(II,III), NiHCF, was considered for potential application as a redox mediator (charge relay) in dye-sensitized solar cell (DSSC). The NiHCF redox reactions were found fast and reversible not only when the system was studied as thin film exposed to an aqueous supporting electrolyte but also as bulk material (pasted powder) in solid state, i.e., in the absence of contact with external liquid electrolyte phase. Usefulness of NiHCF material was diagnosed using conventional electroanalytical approaches, solid-state voltammetric methodology, as well as the dynamic electrochemical impedance spectroscopy technique that permitted monitoring of impedance spectra under potentiodynamic conditions. The material was utilized in a mixed-valent state, i.e., as a mixture of $\mathrm{K}_{4} \mathrm{Ni}^{\mathrm{II}}\left[\mathrm{Fe}^{\mathrm{II}}(\mathrm{CN})_{6}\right]$ and $\mathrm{K}_{3} \mathrm{Ni}^{\mathrm{II}}\left[\mathrm{Fe}^{\mathrm{III}}(\mathrm{CN})_{6}\right]$ in which iron(II) and iron(III) sites were at the 1:1 ratio. Under such conditions, dynamics of electron-hopping between mixedvalent iron sites was maximized. Our DSSC utilized cisdithiocyanoatobis (4,4'-dicarboxylic acid-2,2'-bipyridine) ruthenium(II) dye (N3) adsorbed onto $\mathrm{TiO}_{2}$ semiconductor and NiHCF as redox mediator. Although performance of
\end{abstract}

\footnotetext{
I. A. Rutkowska $\cdot$ S. Zoladek · M. Goral • P. J. Kulesza $(\bowtie)$

Department of Chemistry, University of Warsaw,

Pasteura 1,

02-093 Warsaw, Poland

e-mail: pkulesza@chem.uw.edu.pl

A. Andrearczyk $\cdot K$. Darowicki

Department of Electrochemistry Corrosion and Materials

Engineering, Gdansk University of Technology,

Narutowicza 11/12,

80-233 Gdansk, Poland
}

our DSSC was not optimized in terms of the NiHCF film thickness and morphology, as well as lower photocurrents in comparison to those characteristic of the iodine/iodide based DSSC were obtained, our system yielded readily fairly high open-circuit photovoltages on the level of $800 \mathrm{mV}$. An important issue was that the formal potential of NiHCF was more positive relative to the potential of the iodide/triiodide couple while being still more negative than that equivalent to the ground state of the N3 dye. Thus, NiHCF mediator was able to regenerate the dye.

Keywords Metal hexacyanoferrate $\cdot$ Sol-gel processed deposits $\cdot$ Solid-state voltammetry charge propagation . Charge relay $\cdot$ Solar cell

\section{Introduction}

Recent progress in the area of dye-sensitized solar cells (DSSCs), aiming at the enhancement of their performance, has concerned improvement of morphology of semiconducting materials, optimization of dyes, and the search for novel electrolytes and charge relays (mediators) [1-7]. Successful application of mesoporous $\mathrm{TiO}_{2}$ (anatase) films in DSSCs [1, $8,9]$ was prompted by the systems' nanocrystallinity, highly porous character, and the ability to provide large surface area to adsorb sizeable amounts of dye. The nanostructured morphology of anatase semiconducting particles facilitated interfacial electron transfers to and from dye molecules, close contact, and easy access of the electrolyte ions and charge relay species, thus leading to the appearance of fairly high photovoltages $[10,11]$. Nonporous $\mathrm{TiO}_{2}$ film texture was also of importance when it comes to anchoring photosensitizer (dye) at quasi-monolayer level to ensure efficient light 
harvesting and electron injections. Typical examples of dyes include organometallic compounds in which inorganic element exhibits redox properties in addition to its light sensitivity. The so-called N3 dye, i.e., cis-dithiocyanoatobis (4,4'-dicarboxylic acid-2,2'-bipyridine) ruthenium(II), that is utilized in the present study, can be viewed as a representative example of the robust efficient photosensitizing system.

Charge relay and electrolyte are used not only to permit redox conductivity or appropriate charge propagation between two opposing electrodes but also to ascertain regeneration of a dye. An effective system would be a fast electron-transfer redox mediator (preferably in solid state) characterized by a formal potential fairly close to (but still more negative than) the potential equivalent to energy level of the ground state of the dye used. Although many redox charge relays have been proposed as alternatives to the $\mathrm{I}^{-} / \mathrm{I}_{3}{ }^{-}$redox couple and successfully applied in DSSCs [12-15], the semisolid iodine/iodide-based system (dispersed in the appropriate electrolyte-containing solvent mixture) is so far most commonly used and viewed as the most stable and efficient material. Electrolytes based on volatile organic solvents are rather impractical due to their instability during operation at higher temperatures. Recently, some efforts have been made to replace the organic solvent electrolytes with p-type inorganic semiconductors $[16,17]$, polymer electrolytes $[18,19]$, and organic holetransport materials [20], but their efficiencies still require improvement. Ionic liquid-based electrolytes have been found promising for DSSCs because of their reasonable conductivity and such features as negligible vapor pressure and non-flammability [21].

In the present work, we consider the ionically $\left(\mathrm{K}^{+}\right)$and electronically (mixed-valence electron-hopping) conducting polynuclear inorganic material, namely Prussian Blue type nickel hexacyanoferrate [22-27] as material for potential application in DSSC as solid redox mediator (charge relay). Redox reactions of metal hexacyanoferrates are fast and reversible, and the systems are characterized by very good chemical and mechanical stability. Here, we have chosen nickel(II) hexacyanoferrate(III,II), NiHCF, as a model cyanometallate material [28-30] because it shows welldefined and reproducible responses not only when studied as thin films exposed to aqueous supporting electrolytes but also in solid state, i.e., in the absence of contact with external liquid phase [29-32]. In addition to these important dynamic features, utilization of NiHCF in DSSC is also justified in thermodynamic terms because the system's formal potential is more positive in comparison to that of the $\mathrm{I}_{3}{ }^{-} / \mathrm{I}^{-}$couple (while being still more negative relative to the potential characteristic of the N3 dye's ground energetic state). In this study, we have diagnosed usefulness of $\mathrm{NiHCF}$ using conventional electroanalytical approaches, solid-state voltammetric methodology, as well as dynamic electrochemical impedance spectroscopy (DEIS) technique [33-35] that permits monitoring of impedance spectra under potentiodynamic conditions.

\section{Experimental}

Chemicals, materials, and procedures

All chemicals were analytical grade materials and were used as received. Solutions were prepared from the distilled and subsequently deionized water.

Conventional thin films of nickel hexacyanoferrate on glassy carbon electrode were fabricated by electrodeposition through potential cycling (from 0.85 to $0 \mathrm{~V}$ for $10 \mathrm{~min}$ at $\left.50 \mathrm{mV} \mathrm{s}^{-1}\right)$ in the solution $\left(50 \mathrm{~cm}^{3}\right)$ formed by mixing $49 \mathrm{~cm}^{3} 1.0 \mathrm{~mol} \mathrm{dm}^{-3} \mathrm{KCl}$ with $0.5 \mathrm{~cm}^{3} 0.1 \mathrm{~mol} \mathrm{dm}^{-3} \mathrm{~K}_{3} \mathrm{Fe}$ $(\mathrm{CN})_{6}, 0.5 \mathrm{~cm}^{3} 0.1 \mathrm{~mol} \mathrm{dm}^{-3} \mathrm{NiCl}_{2}$.

The oxidized or reduced form (bulk material) of nickel hexacyanoferrate, NiHCF, was prepared by precipitation (via dropwise mixing) of equivalent amounts of $0.01 \mathrm{~mol} \mathrm{dm}^{-3}$ solutions: $\mathrm{K}_{3} \mathrm{Fe}(\mathrm{CN})_{6}$, or $\mathrm{K}_{4} \mathrm{Fe}(\mathrm{CN})_{6}$, with $0.01 \mathrm{~mol} \mathrm{dm}^{-3}$ $\mathrm{NiSO}_{4}$ (containing $0.01 \mathrm{~mol} \mathrm{dm}{ }^{-3}$ EDTA and $0.5 \mathrm{~mol} \mathrm{dm}^{-3}$ $\mathrm{K}_{2} \mathrm{SO}_{4}$ adjusted to $\mathrm{pH}=4$ with diluted $\mathrm{H}_{2} \mathrm{SO}_{4}$ ). The procedure was analogous to that described earlier except that it involved addition of EDTA. It is noteworthy that EDTA forms complexes with $\mathrm{Ni}^{2+}$ ions, and its presence in the solution results in slower precipitation of NiHCF as well as in the formation of more compact system's granules typically on sub-micrometer (down to tens of nanometer) level. As a rule, suspensions of both oxidized and reduced NiHCF forms were left overnight to complete precipitation. They were subsequently mixed (under magnetic stirring) to produce NiHCF suspension containing mixed-valence $-\mathrm{Fe}^{\mathrm{III}, \mathrm{II}}(\mathrm{CN})_{6}$ sites at approximately 1:1 ratio. The resulting precipitate was filtered, rinsed carefully with water, and air-dried for $24 \mathrm{~h}$ before grinding with pestle and mortar. The degree of hydration (approximately 10-15 stoichiometric water molecules per

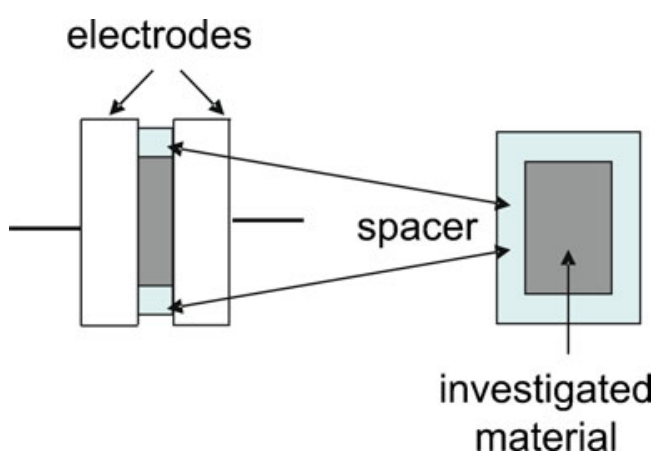

Fig. 1 Two-electrode design for solid-state voltammetric measurements performed in the absence of liquid electrolyte phase 
$\mathrm{NiHCF}$ unit) was estimated from the hydrogen content (elemental analysis).

Mesoporous $\mathrm{TiO}_{2}$ films (thickness, approximately $2.5 \mu \mathrm{m})$ were prepared from commercial Degussa P25 $\mathrm{TiO}_{2}$ powder (average diameter of particles, $25 \mathrm{~nm}$ ) composed of approximately $80 \%$ anatase and $20 \%$ rutile. They were deposited on conducting F-doped $\mathrm{SnO}_{2}$-coated glass (sheet resistance, $10 \Omega$ per square) by spray pyrolysis as described elsewhere [36]. Mesoporous $\mathrm{TiO}_{2}$ layers were pressed onto the spray layer using the approach described before [37]. Here $2 \mathrm{~g}$ of $\mathrm{TiO}_{2}$ powder (Degussa P25, average diameter $25 \mathrm{~nm}$ ) was suspended in $10 \mathrm{ml}$ of pure ethanol by stirring for several hours, followed by sonication for 5 min using the titanium horn immersed in the suspension. The slurry was spread onto the surface of the $\mathrm{SnO}_{2} / \mathrm{TiO}_{2}$ substrate by tape-casting, i.e., by using one or more layers of scotch tape $(50 \mu \mathrm{m})$ as spacers. The resulting layer of ethanol/ $\mathrm{TiO}_{2}$ was allowed to dry in the ambient atmosphere. The $\mathrm{TiO}_{2}$ layers were then heated for $2 \mathrm{~h}$ at $500{ }^{\circ} \mathrm{C}$ in air. Films were removed from the oven at $\sim 100{ }^{\circ} \mathrm{C}$ and placed in ethanolic solutions of the dye "N3", which is $\mathrm{RuL}_{2}(\mathrm{SCN})_{2}$ where $L=4,4^{\prime}$-dicarboxy-2,2'-bipyridine. The dye was purchased from Solaronix under the name Ruthenium 535. After being dyed overnight, the films were rinsed in ethanol and dried in a stream of compressed air. Before experiments, the photoelectrode was conditioned for $30 \mathrm{~min}$ in the freshly prepared solution obtained by mixing of equimolar amounts of $1 \mathrm{mmol} \mathrm{dm} \mathrm{dm}^{-3} \mathrm{Ni}^{2+}$ and $1 \mathrm{mmol} \mathrm{dm}{ }^{-3} \mathrm{Fe}(\mathrm{CN})_{6}{ }^{3-}$ solutions. Slow precipitation of nickel hexacyanoferrate (by sol-gel aggregation) permitted its deposition in the titanium oxide pores.

The nickel hexacyanoferrate-modified dye-adsorbed $\mathrm{TiO}_{2}$ electrode and counter electrode (platinized F-doped $\mathrm{SnO}_{2}$-coated glass) were assembled into a sealed sandwichtype cell in which pasted $\mathrm{NiHCNFe}$ powder was introduced between electrodes and the spacing between them (approximately $0.6 \mathrm{~mm}$ ) was controlled by introducing an appropriate spacer cutout from cardboard paper. The active area of DSSC was fixed to $0.3 \mathrm{~cm}^{2}$.

\section{Diagnostic electrochemical measurements}

The cell for solid-state (namely in the absence of an external phase of supporting electrolyte) voltammetric experiments utilized two inert glassy carbon slide electrodes (Fig. 1) mounted in a sandwich configuration [30-32] of the $0.3 \mathrm{~cm}^{2}$ geometric area. The spacing between electrodes (approximately $0.6 \mathrm{~mm}$ ) was controlled by introducing a spacer cutout from cardboard paper.

The cyanometallate material of mixed-valent $\mathrm{NiHCF}$ was introduced (pasted) onto each sandwich-forming glassy carbon electrode. When using a three-electrode potentiostat, the operation of a cell in two-electrode mode implied that one of these two electrodes was connected as a working electrode and the second one acted as reference and counter electrodes simultaneously [30, 31]. To assure good contact of electrodes with the material, a pressing weight was used. The assembly was enclosed in Teflon tubing and sealed to protect the material from dehydration.

DEIS measurements were performed in a manner described earlier [33-35]. AC perturbation signal was a package of 20, selected sinusoids of different amplitudes, generated by a DXI 6120 National Instruments measurement card. The perturbation signal and additional DC component generated by an Agilent 33120 generator were sent to a KGLstst 4.1 potentiostat. Current-voltage response and the additional voltage signal were registered with PXI-1031DC National Instruments measurement card. The measurement setup was controlled with the LabVIEW software (National Instruments).

Conventional electrochemical measurements were done in a three-electrode mode using $\mathrm{CH}$ Instruments (Austin, TX, USA) model 660 analyzer. All potentials were expressed versus the $\mathrm{KCl}$ saturated $\mathrm{Ag} / \mathrm{AgCl}$ reference.

\section{Photoelectrochemical measurements}

The photoaction spectra were determined using a $500-\mathrm{W}$ xenon lamp (Ushio UXL-502HSO) set in an Oriel Model 66021 housing and a Multispec 257 monochromator (Oriel) with a bandwidth of $4 \mathrm{~nm}$.

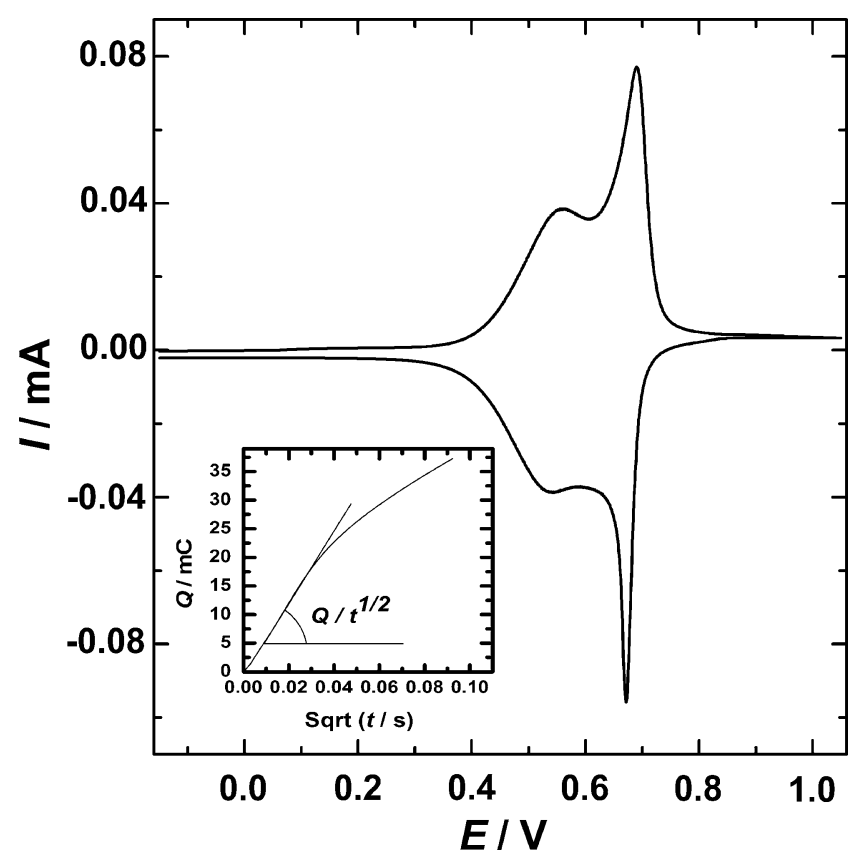

Fig. 2 Cyclic voltammetric response of NiHCF film on glassy carbon electrode recorded in $0.5 \mathrm{~mol} \mathrm{dm}{ }^{-3} \mathrm{~K}_{2} \mathrm{SO}_{4}$. Scan rate, $50 \mathrm{mV} \mathrm{s}{ }^{-1}$. Inset illustrates chronocoulometric response obtained upon application of the anodic potential step from 0 to $0.85 \mathrm{~V}$ 


\section{Results and discussion}

Diagnostic electrochemical measurements

The response of a conventional nickel(II) hexacyanoferrate (II,III) (NiHCF) film on glassy carbon (Fig. 2) is characterized by overlapping redox reactions at about $0.4-0.6 \mathrm{~V}$. Although the approximate formulas $\mathrm{KNi}_{1.5}\left[\mathrm{Fe}^{\mathrm{II}}(\mathrm{CN})_{6}\right]$ and $\mathrm{K}_{2} \mathrm{Ni}\left[\mathrm{Fe}^{\mathrm{II}}(\mathrm{CN})_{6}\right]$ are usually assigned to two predominant forms of the reduced $\mathrm{NiHCF}$ films, in reality the films are electrodeposited (in the presence of $\mathrm{K}^{+}$ions) in the form of solid solutions rather than homogeneous phases. The most important observation coming from the above experiments with thin film of nickel(II) hexacyanoferrate(II,III) (exposed to liquid $\mathrm{K}^{+}$-containing electrolyte) is the fact that
NiHCF redox transitions, as well as the ability to act as redox mediator, appear at fairly positive potentials (approximately $0.4-0.6 \mathrm{~V}$ vs. $\mathrm{Ag} / \mathrm{AgCl}$ ).

In order to be more quantitative about dynamics of charge transport during redox reactions in the NiHCF film described above, we have recorded dependencies (inset of Fig. 2) of the chronoculometric charge $(Q)$ on the square root of time $\left(t^{1 / 2}\right)[30,31]$ upon application of the potential step from 0 to $0.85 \mathrm{~V}$. The appearance of linear portion in the chronocoulometric plot implies existence of the diffusional type pattern. Under such conditions, the dependence of $Q$ on $t^{1 / 2}$ can be effectively described in terms of the integrated Cottrell equation:

$$
\left[Q / t^{1 / 2}\right]=2 n F \pi^{1 / 2} r^{2}\left[D_{\text {app }}{ }^{1 / 2} C_{0}\right]
$$

Fig. 3 DEIS impedance spectra obtained for the NiHCF film (as for Fig. 2) during a oxidation and $\mathbf{b}$ reduction cycles
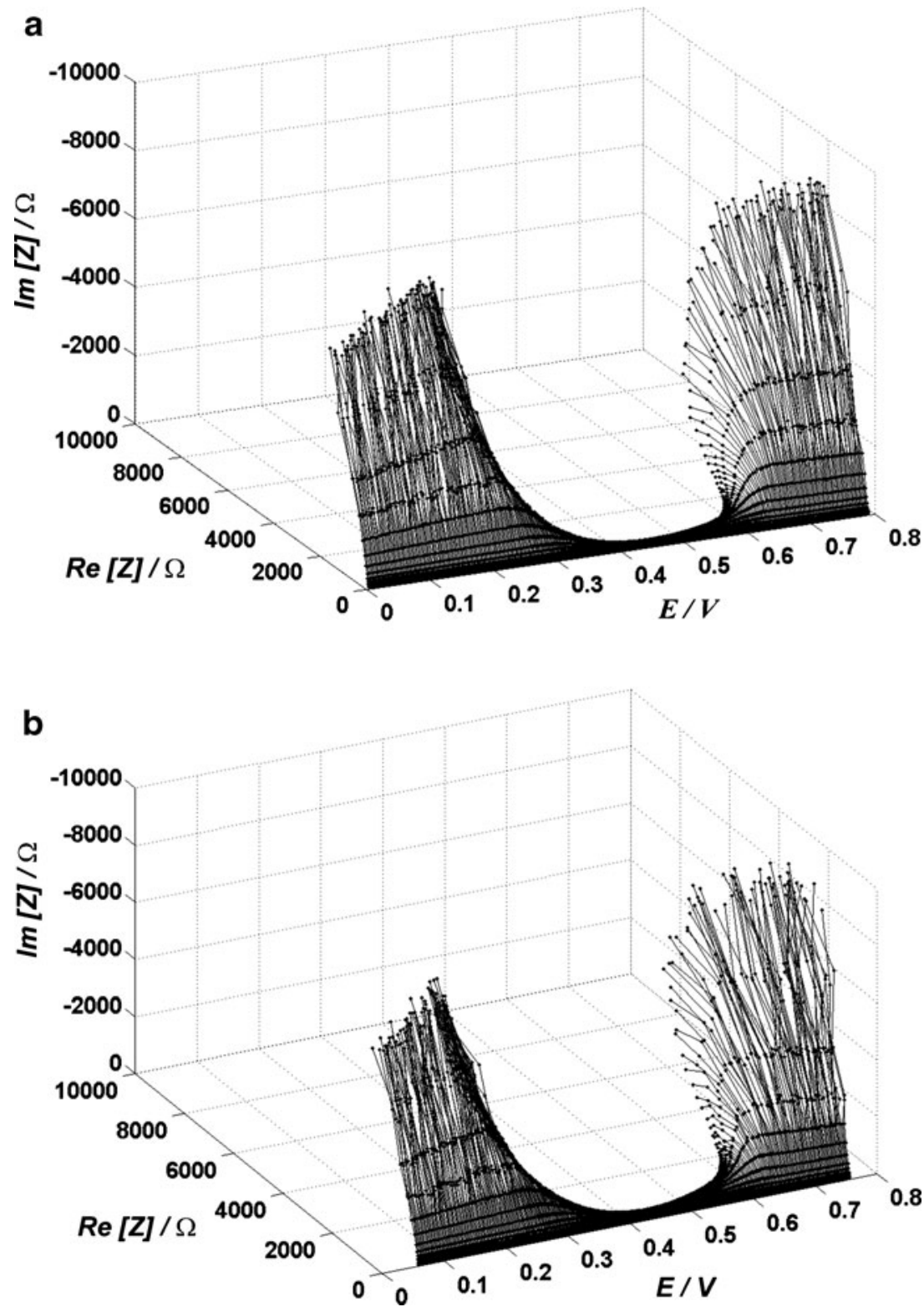
propagation, concentration of redox centers, and other parameters either have been discussed above or have their usual significance. From the slope, $\left[Q / t^{1 / 2}\right]$, which is determined from the linear portion of the dependence of $Q$ on $t^{1 / 2}$, the kinetic parameter, $\left[D_{\mathrm{app}}{ }^{1 / 2} C_{0}\right]$ can be estimated. The absence of any sizeable negative intercept in the chronocoulometric plot (Fig. 2, inset) permits us to assume that kinetic or ohmic limitations are relatively negligible. Estimation of the apparent diffusion coefficient $\left(D_{\text {app }}\right)$ has been achieved from the integrated Cottrell equation (Eq. 1) upon assumption of $C_{0}=0.5 \mathrm{~mol} \mathrm{dm}^{-3}$ $[23,28]$. Thus, $D_{\text {app }}$ values obtained for NiHCF film exposed to $0.5 \mathrm{~mol} \mathrm{dm}{ }^{-3} \mathrm{~K}_{2} \mathrm{SO}_{4}$ electrolyte have been found in the range from $5 \times 10^{-9}$ to $6 \times 10^{-9} \mathrm{~cm}^{2} \mathrm{~s}^{-1}$, and they are comparable to those reported earlier in $\mathrm{KCl}$ electrolyte [28].

To get better insight into the system's ability to propagate charge, the NiHCF films on glassy carbon were further analyzed using recently proposed and developed approach, DEIS [33-35]. In the first step, the perturbation signal (being the sum of selected sine waves of set frequencies, phases shifts, and amplitude) was composed in a manner described earlier [33-35] and, subsequently, provided to the potential input of a potentiostat. Later, a short-time Fourier transform analysis was utilized to obtain the impedance spectra for the electrochemical processes. Figure 3 illustrates the impedance spectra obtained for the NiHCF film (as for Fig. 2) during (a) oxidation and (b) reduction cycles. While the frequency range was from 20 to $16,000 \mathrm{~Hz}$, the sampling frequency was 40,000 samples per second, and the window length covered 4,000 samples. Furthermore, the frequency resolution was $10 \mathrm{~Hz}$, and each spectrum was calculated for a region of the dc voltage change of $3 \mathrm{mV}$. It is noteworthy that both anodic (Fig. 3a) and cathodic (Fig. 3b) portions of spectra have regular forms [33-35]. In particular, the observed lines are iso-frequency lines that change monotonically with the applied potential. The observed minima (Fig. 3) correspond to the respective oxidation and reduction peaks of Fig. 2. An important issue is that, in the 0.4-0.6 potential range, the charge-transfer resistances of both anodic and cathodic processes drastically diminish and make electron transfers (charge mediation) feasible.

Solid-state electrochemical characterization

Because the intended application of NiHCF is as mediating material in the absence of contact with liquid electrolyte, further diagnostic experiments have been done using the appropriate solid-state methodology. The feasibility of performing solid-state voltammetric measurements of mixed-valent NiHCF pressed pastes under sandwich configuration was established earlier [32]. The mobility of structural $\mathrm{K}^{+}$ions was found to be strongly dependent on the system's degree of hydration. Under typical ambient conditions (80-90\% humidity), the systems were sufficiently hydrated (around eight to ten molecules per metal hexacyanoferrate) to assure good mobility of potassium ions. The transport of electrons was explained in terms of electron hopping (self-exchange). In the absence of liquid electrolyte, electron transfers were coupled to the displacement of structural counterions (hydrated $\mathrm{K}^{+}$) and, thus, elelectroneutrality was preserved. Furthermore, solid-state voltammetric investigations are possible under twoelectrode sandwich configuration because a mixed-valent NiHCF system contains hexacyanoferrate(III,II) redox centers that can be simultaneously oxidized or reduced at interfaces formed by the opposing electrodes [30, 31]. A representative solid-state voltammetric-type response (current versus applied potential differences) of our mixedvalent NiHCF nickel(II) hexacyanoferrate(II,III) material (pasted powder) is shown in Fig. 4. As expected, for twoelectrode solid-state voltammetry (sandwich configuration), the response is in a form of voltammetric peaks symmetrical around the point of zero with respect to current and potential. It should be remembered that the cell operates in a manner analogous to classical biamperometry in which potential differences are applied to two identical electrodes and scanned linearly with time. It is noteworthy that the voltammetric peak currents of Fig. 4 are proportional to the square root of scan rate up to at least $250 \mathrm{mV} \mathrm{s}^{-1}$ (inset of

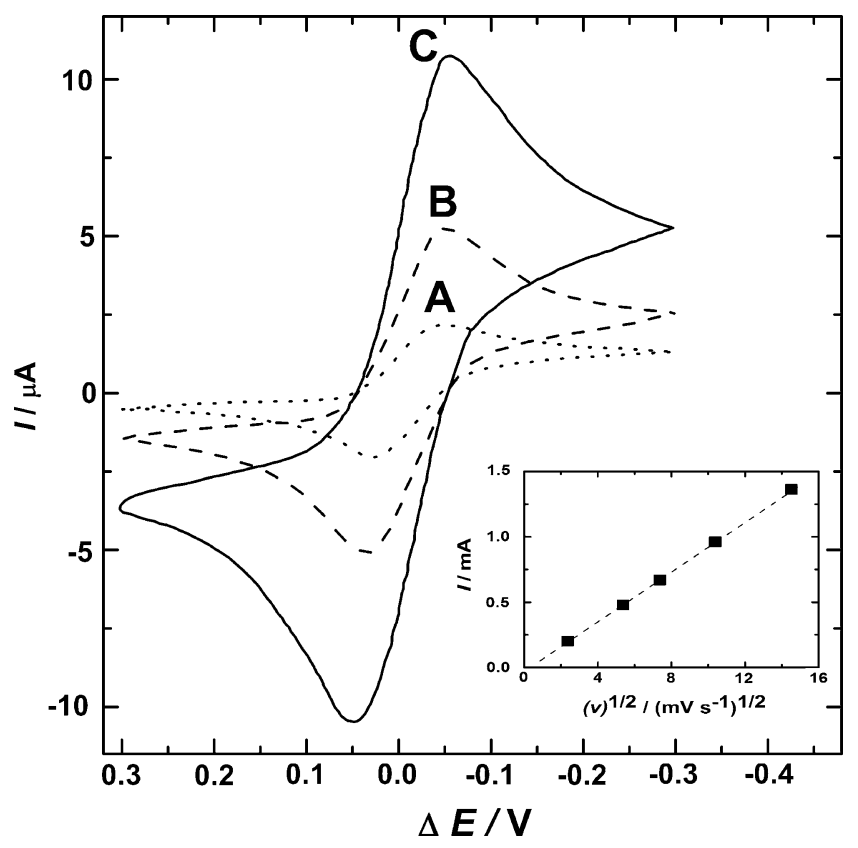

Fig. 4 Solid-state cyclic voltammetric responses for nickel(II) hexacyanoferrate(III,II) [1:1] bulk material (powder) that was pressed between two sandwich-forming electrodes of the design of Fig. 1. $\mathrm{Scan}$ rate, $10 \mathrm{mV} \mathrm{s}^{-1}$. Inset illustrates the peak current dependence on scan rate 
Fig. 4). The result is consistent with the existence of the effectively diffusional charge propagation mechanism predominantly driven by electrochemically generated concentration gradients of mixed-valence hexacyanoferrate(II,III) sites across the sandwiched material. The currents are obviously maximized when the ration of $\mathrm{Fe}^{\mathrm{II}}$ to $\mathrm{Fe}^{\mathrm{III}}$ sites is equal 1:1, i.e., under conditions where the concentration of the hexacyanoferrate(III,II) mixed-valent sites is the largest. Completely reduced or oxidized nickel hexacyanoferrate pastes are not electroactive under two-electrode sandwich configuration.

Another important issue is the degree of hydration because $\mathrm{K}^{+}$ions are transported in the hydrated form. It was reported earlier that the $\mathrm{K}^{+}$cation mobility was largely impeded upon dehydration [32]. Although not optimized yet, we have found that the NiHCF material containing roughly 10 to 15 stoichiometric water molecules is a wellbehaved system for which the applied potential differences are capable of forcing not only electrons but also mobilehydrated $\mathrm{K}^{+}$ions to flow in response. In such a solid material as $\mathrm{NiHCFe}$, the metal (iron) redox sites are immobilized, the macroscopic diffusion does not operate, and the actual mass transport originates from the simultaneous displacement of electron and mobile counterions. On the whole, we can conclude that, in the absence of the external liquid electrolyte phase, NiHCF pressed pastes can act as mediators in which propagation of charge proceeds effectively according to diffusional mechanism.

\section{Performance of solar cell with inorganic mediator}

Figure 5 illustrates a design of a DSSC utilizing inorganic mediator (NiHCF). The photoanode is made of mesoporous dye-sensitizer $\mathrm{TiO}_{2}$ semiconductors. It receives electron from the photo-excited dye, which is thereby oxidized, and which in turn oxidized the mediator, a redox species dissolved in electrolyte. The mediator (the oxidized form of nickel(II) hexacyanoferrate(III)) is regenerated by reduction at the cathode by the electrons circulated through the external circuit. Cathode is in a form a platinized conducting glass electrode. Excited dye is in the cationic form while it is transferring e- to the $\mathrm{TiO}_{2}$ conducting band. The dye (Fig. 6) is capable of oxidizing the reduced form, nickel (II) hexacyanoferrate(II). The sequence of reactions in our dye-sensitizer solar cell is as follows:

dye $+h v \rightarrow$ dye*

dye* $\rightarrow$ dye $^{+}+\mathrm{e}_{\mathrm{TiO} 2}^{-}$

$\mathrm{dye}^{+}+\mathrm{K}_{2} \mathrm{Ni}^{\mathrm{II}}\left[\mathrm{Fe}^{\mathrm{II}}(\mathrm{CN})_{6}\right] \rightarrow \mathrm{KNi}^{\mathrm{II}}\left[\mathrm{Fe}^{\mathrm{III}}(\mathrm{CN})_{6}\right]+\mathrm{K}^{+}+$dye

The overall reaction occurring at the photoanode may be represented simply as:

$$
\begin{gathered}
\mathrm{TiO}_{2} / \text { dye }+h v+\mathrm{K}_{2} \mathrm{Ni}^{\mathrm{II}}\left[\mathrm{Fe}^{\mathrm{II}}(\mathrm{CN})_{6}\right] \\
\rightarrow \mathrm{KNi}^{\mathrm{II}}\left[\mathrm{Fe}^{\mathrm{III}}(\mathrm{CN})_{6}\right]+\mathrm{e}^{-}+\mathrm{K}^{+}
\end{gathered}
$$

Although the formal potential of our system-nickel hexacyanoferrate (approximately $0.6 \mathrm{~V}$ vs. SCE) is still more negative than that (approximately $0.85 \mathrm{~V}$ vs. SCE) of the ground state of N3 dye [cis-dithiocyanoatobis (4,4'dicarboxylic acid-2,2'-bipyridine) ruthenium(II)], an important issue is that the potential is more positive relative to the
Fig. 5 Design of dye-sensitizer solar cell in which mixed-valent NiHCF pasted powder of Fig. 4 was used as inorganic charge relay (redox mediator). Approximate values of redox potentials of the $-\mathrm{Ni}^{\mathrm{II}}\left[\mathrm{Fe}^{\mathrm{III}, \mathrm{II}}(\mathrm{CN})_{6}\right]$ system, the commonly used $\mathrm{I}^{-} / \mathrm{I}_{3}{ }^{-}$ couple and of the dye $\left(\mathrm{S}^{+} / \mathrm{S}\right)$ are compared using the calomel electrode scale

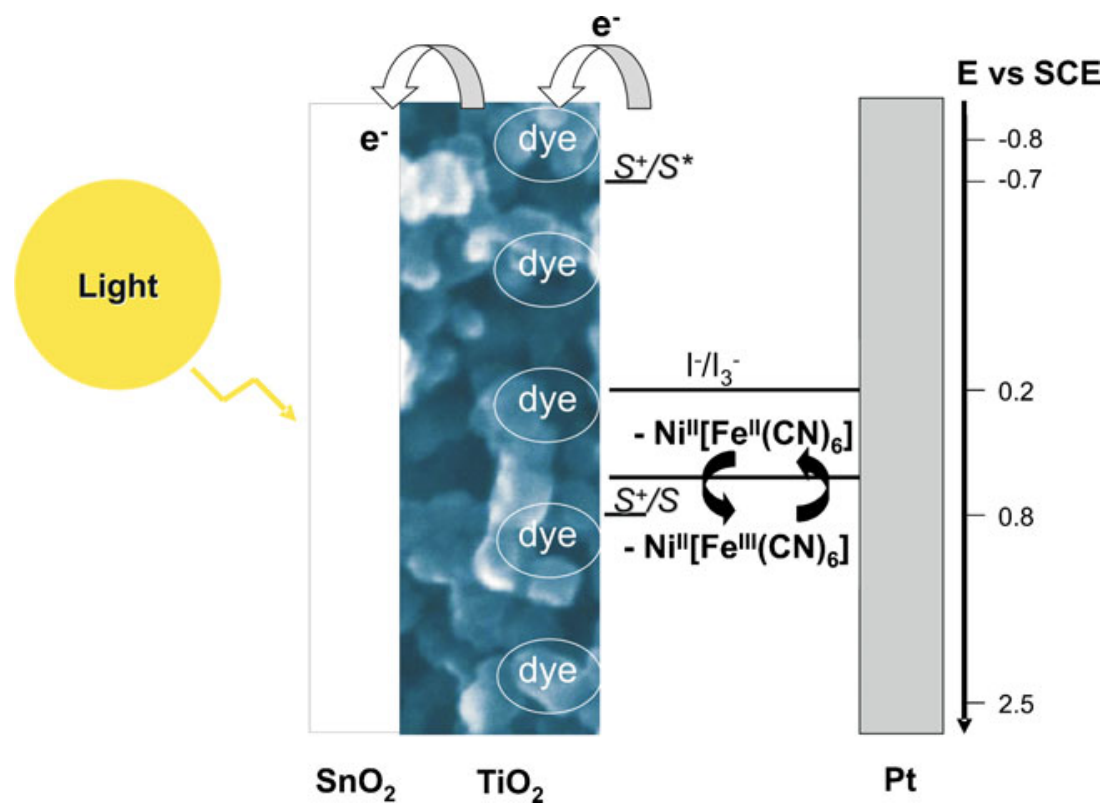


<smiles></smiles>

N3

Fig. 6 Molecular structure of the N3 dye

iodide/triiodide couple $(0.15 \mathrm{~V}$ vs. SCE). In principle, the latter phenomenon should result in larger photopotentials produced by the photocell.

Figure 7 shows the photocurrent action spectrum of a typical cell under short-circuit conditions. The given values are not corrected for reflection and absorption losses. The spectrum closely matches the absorption spectrum of the dye $[1,8]$ thus confirming that the observed photocurrent arises from electron injection by the sensitizer. The maximum value of photocurrent occurs at $560 \mathrm{~nm}$.

Figure 8 illustrates dependence of the density of generated photocurrent on potential. Under the one-sun illumination of the cell, a short-circuit photocurrent density of $8 \mathrm{~mA} / \mathrm{cm}^{2}$ is produced. Along with the voltage of $790 \mathrm{mV}$ and fill factor of 0.7 , the result implies the energy efficiency exceeding $4 \%$ (at one sun).

The data of Fig. 9 are consistent with the reproducible behavior during multiple photoelectrochemical experi-

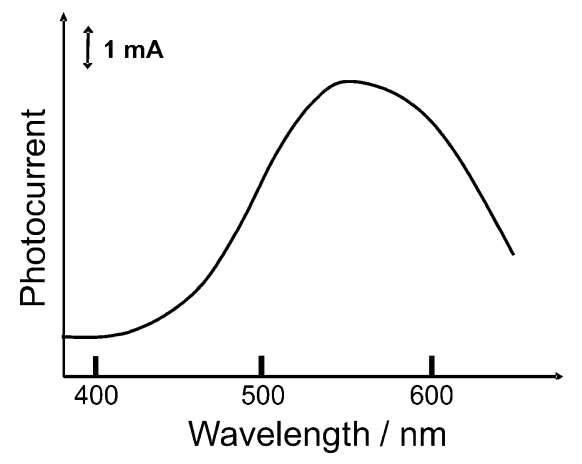

Fig. 7 Action spectrum of the dye-sensitized solar cell (DSSC) utilizing NiHCF charge relay. Light intensity, 1.5 full sunlight $\left(100 \mathrm{~mW} / \mathrm{cm}^{2}\right)$

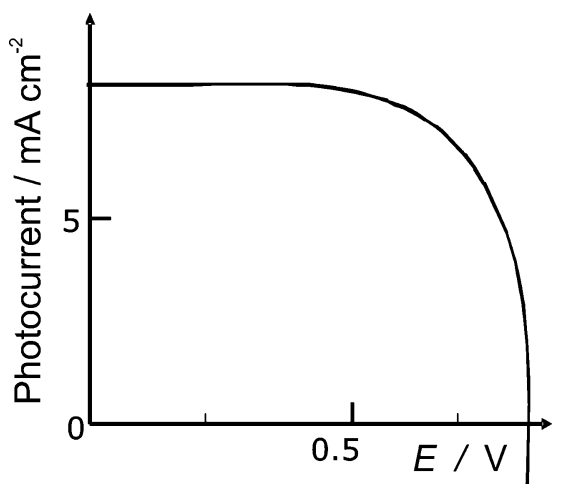

Fig. 8 Photocurrent density-voltage characteristics of DSSC utilizing $\mathrm{NiHCF}$ charge relay. Light intensity, 1.5 full sunlight $\left(100 \mathrm{~mW} / \mathrm{cm}^{2}\right)$

ments. Several cells have been examined, and all of them here produced comparable short-circuit current densities (within $\pm 20 \%$ ). During repetitive long-time measurements, almost identical photocurrents are obtained. After 3 days of intense utilization, the system has been still stable, and the photocurrent produced was reproducible within $\pm 20 \%$.

\section{Conclusions}

On the basis of our measurements with nickel(II) hexacyanoferrate(II,III), i.e., the polynuclear inorganic mediator, it can be concluded that such a mixed-valent cyanometallate system (pasted powder) is capable of fairly fast charge propagation involving electron transfers accompanied by structural potassium counterion displacements [23, 32, 38]. Such inorganic structures can form conducting interface with the nanostructured dye-modified semiconductor. The mixed-valent metal hexacyanoferrate can act as solid inorganic charge redox mediator characterized by fairly positive potential. Although morphology of the redox mediator has not been optimized yet, pasted powders of nickel(II) hexacyanoferrate(II,III) could be of utility as a charge relay in a dye-sensitized solar cell.

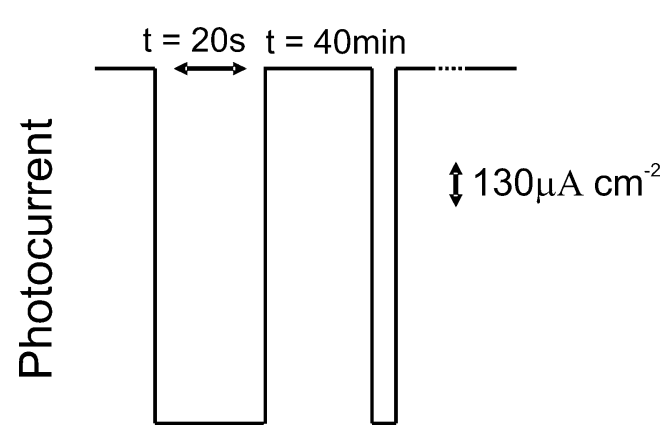

Fig. 9 Multiple illumination pulses on the NiHCF-containing DSSC. Light intensity, 1.5 full sunlight $\left(100 \mathrm{~mW} / \mathrm{cm}^{2}\right)$ 
Acknowledgments This work was supported by Ministry of Science and Higher Education (Poland) under grant no. N204 031235.

Open Access This article is distributed under the terms of the Creative Commons Attribution Noncommercial License which permits any noncommercial use, distribution, and reproduction in any medium, provided the original author(s) and source are credited.

\section{References}

1. O'Regan B, Graetzel M (1991) Nature 353:737

2. Benkstein KD, Kopidakis N, van de Lagemaat J, Frank AJ (2003) J Phys Chem B 107:7759

3. Benkoe G, Skarman B, Wallenberg R, Hagfeldt A, Sundstroem V, Yartsev AP (2003) J Phys Chem B 107:1370

4. Nakade S, Saito Y, Kubo W, Kitamura T, Wada Y, Yanagida S (2003) J Phys Chem B 107:8607

5. Nazeeruddin MK, Pechy P, Renouard T, Zakeeruddin SM, Humphry-Baker R, Liska P, Cevey L, Costa E, Shklover V, Spiccia L, Deacon GB, Bignozzi CA, Graetzel M (2001) J Am Chem Soc 123:1613

6. Thomas KRJ, Lin JT, Hsu YC, Ho KC (2005) Chem Commun 4098

7. Velusamy M, Thomas KRJ, Lin JT, Hsu YC, Ho KC (2005) Org Lett 7:1899

8. O'Regan B, Moser J, Anderson M, Graetzel M (1990) J Phys Chem 9:8720

9. Nazeerudin MK, Kay A, Rodicio I, Humphrey-Baker R, Mueller E, Liska P, Vlachopoulos N, Graetzel M (1993) J Am Chem Soc 115:6382

10. Cahen D, Hodes G, Graetzel M, Guillemoles JF, Riess I (2000) J Phys Chem B 104:2053

11. Chen X, Mao SS (2007) Chem Rev 107:2891

12. Wang P, Zakeeruddin SM, Moser JE, Humphry-Baker R, Graetzel M (2004) J Am Chem Soc 126:7164

13. Nusbaumer H, Zakeeruddin SM, Moser JE, Graetzel M (2003) Chem Eur J 9:3756

14. Nusbaumer H, Moser JE, Zakeeruddin SM, Nazeeruddinm MK, Graetzel M (2001) J Phys Chem B 105:10461

15. Sapp SA, Elliot M, Contado C, Caramori S, Bignozzi CA (2002) J Am Chem Soc 124:11215
16. O'Regan B, Lenzmann F, Muis R, Wienke J (2002) Chem Mater 14:5023

17. Kumara GRA, Kaneko S, Okuya M, Tennakone K (2002) Langmuir 18:10493

18. Nogueira AF, Durrant JR, DePaoli MA (2001) Adv Mater 13:826

19. Stergiopoulos T, Arabatzis IM, Katsaros G, Falaras P (2002) Nano Lett 2:1259

20. Bach U, Lupo D, Comte P, Moser JE, Weissortel F, Salbeck J, Spreitzer H, Graetzel M (1998) Nature 395:583

21. Wasserscheid P, Welton T (2002) Ionic liquids in synthesis. Wiley$\mathrm{VCH}$, Weinheim

22. Lin C, Bocarsly AB (1991) J Electroanal Chem 300:325

23. Malik MA, Miecznikowski K, Kulesza PJ (2000) Electrochim Acta 45:3777

24. Joseph J, Gomathi H, Prabhakara Rao G (1991) Electrochim Acta $36: 1537$

25. Kubota LT, Gushikem Y (1993) J Electroanal Chem 362:219

26. Bacskai J, Martinusz K, Czirok E, Inzelt G, Kulesza PJ, Malik MA (1995) J Electroanal Chem 385:241

27. Kulesza PJ, Malik MA, Schmidt R, Smolinska A, Miecznikowski K, Zamponi S, Czerwinski A, Berrettoni M, Marassi R (2000) J Electroanal Chem 487:57

28. Malik MA, Kulesza PJ, Marassi R, Nobili F, Miecznikowski K, Zamponi S (2004) Electrochim Acta 49:4253

29. Zamponi S, Berrettoni M, Kulesza PJ, Miecznikowski K, Malik MA, Makowski O, Marassi R (2003) Electrochim Acta 48:4261

30. Kulesza PJ, Malik MA (1999) In: Wieckowski A (ed) Interfacial electrochemistry - theory, experiment and applications, solid-state voltammetry 673. Marcel Dekker, New York

31. Kulesza PJ, Cox JA (1998) Electroanalysis 10:73

32. Kulesza PJ, Galus Z (1992) J Electroanal Chem 323:261

33. Darowicki K (2000) J Electroanal Chem 486:101

34. Darowicki K, Slepski P (2003) J Electroanal Chem 547:1

35. Darowicki K, Kawula J (2004) Electrochim Acta 49:4829

36. O'Regan B, Schwartz DT (1996) J Appl Phys 80:4749

37. Lindstrom H, Magnusson E, Holmberg A, Sodergren S, Lindquist SE, Hagfeldt A (2002) Solar Energy Mater Solar Cells 73:91

38. Kulesza PJ, Dickinson VE, Williams ME, Hendrickson S, Malik MA, Miecznikowski K, Murray RW (2001) J Phys Chem B 105:5833 